\section{Hersenactiviteit alzheimerpatiënten in beeld gebracht}

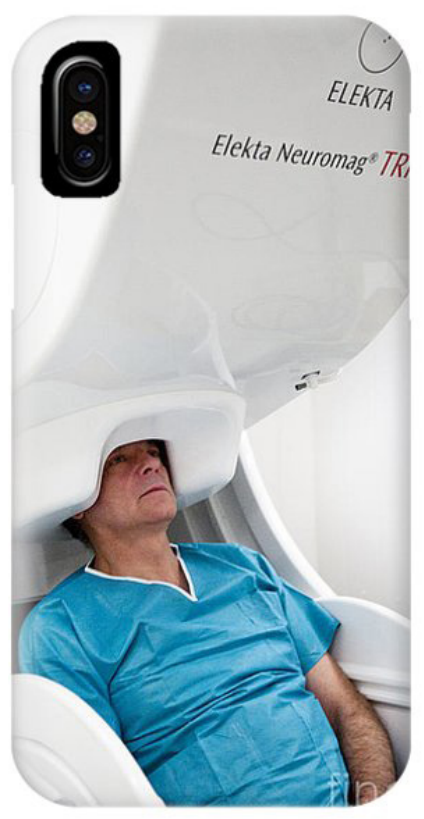

Neurowetenschapper Marjolein Engels heeft voor haar promotieonderzoek de hersenactiviteit van alzheimerpatiënten nauwkeurig in kaart gebracht met behulp van MagnetoEncephaloGrafie (MEG). Zo heeft zij belangrijke informatieknooppunten in de hersenen gelokaliseerd die bij de ziekte van Alzheimer aan-

getast zijn. Beschadiging van zo'n knooppunt heeft een grotere invloed op de werking van het netwerk dan wanneer een ander hersengebied is aangetast. Daarnaast is met de scans gekeken naar de communicatie tussen verschillende hersengebieden. Die bleek bij mensen met alzheimer een stuk trager dan bij gezonde personen. En hoe ernstiger de ziekte, hoe slechter de communicatie tussen de verschillende delen van het brein. 'De bevindingen hebben ons meer inzicht gegeven in de ziekte, wat een essentiële stap is om over oplossingen te gaan nadenken,' aldus Engels. Bron: www.vumc.nl/onderzoek/promoties.

Samenstelling: Sacha Buddingh'. Met medewerking van Peter Bakens, Lies Orthmann, Martin Smalbrugge en Patrick Verhaest. Heeft u een interessant nieuwtje voor deze rubriek: M.Strauss@bsl.nl.

\title{
Leren fluisteren
}

CAROLIEN SMITS

Meer informatie over AlzheimerFluisteren voor het beroepsonderwijs is te verkrijgen bij Gözde Duran, coördinator ProMemo: g.duran@windesheim.nl.

$\mathrm{T}$ heatermaakster Adelheid Roosen heeft ons in haar voorstellingen en de film Mam een 'ander' gezicht laten zien van dementie. Een gezicht dat misschien wel échter is dan wat ik als onderzoeker gewend ben te beschrijven. Want beschrijvingen zijn maar woorden die voortkomen uit onze cortex en iedereen weet dat het niet om woorden gaat, maar om de ervaring van dementie: om emoties, om zintuigen, lichaam en ziel.

Samen met Cigdem Yuksel en Anne-Marth Hogewoning ontwikkelde Roosen het AlzheimerFluisteren. Deze methodiek nodigt mensen uit om letterlijk en figuurlijk mee te bewegen met hun familielid met dementie. Zo kunnen ze hen volgen down the rabbit hole, het konijnenhol waar Alice in tuimelde en haar Wonderland aantrof. Dat meebewegen is een andere taal waarvoor mensen eerst hun gêne moeten overwinnen om elkaar eindeloos vast te durven houden. AlzheimerFluisteren doorbreekt die gêne door je je bewust te laten worden van wat je verlegen maakt en daar een beeld bij te bedenken. Dat beeld wordt gevangen in een foto die de basis vormt om jezelf te spiegelen met de mensen om je heen. AlzheimerFluisteraar Gerard over zíjn foto, waarop hij bij zijn moeder in bed ligt: "s Nachts als ze alleen in haar bed overvallen wordt door angsten ben ik er niet. Op dat soort momenten trekt MAMA onmachtig aan haar pyjama tot de stof scheurt en aan flarden gaat. Op die momenten zou ik naast haar willen liggen, maar ik voel me bezwaard: een volwassen man die naast zijn moeder gaat liggen, kan dat wel?'

Zou het niet mooi zijn als verzorgenden en verpleegkundigen ook door het konijnenhol konden tuimelen, mét de mensen die ze verzorgen? Die gedachte was aanleiding voor Hogeschool Windesheim om de methodiek van het AlzheimerFluisteren te vertalen naar het beroepsonderwijs. De didactische basis wordt gevormd door de cirkel van spiegelen - visualiseren - toepassen. Docenten krijgen workshops om ermee te leren werken en studenten doen oefeningen en maken praktijkopdrachten. Een aanrader voor iedere zorgprofessional die aangeleerd gedrag wil doorbreken en aansluiting wil zoeken bij de subcortex van mensen met dementie. 